\title{
EFEKTIVITAS SPIRITUAL EMOTIONAL FREEDOM TECHNIQUE (SEFT) UNTUK MENURUNKAN KECEMASAN SANTRI BARU DITINJAU DARI TIPE KEPRIBADIAN
}

\author{
Rizki Maulana Hidayatullah', IGAA Noviekayati², Sahat Saragih ${ }^{3}$ \\ Universitas 17 Agustus 1945 Surabaya
}

\begin{abstract}
Abstrak
Penelitian ini bertujuan menguji efektivitas SEFT untuk menurunkan kecemasan santri baru ditinjau dari tipe kepribadian introvert dan ekstrovert. Hipotesis penelitian ini terdapat pengaruh SEFT untuk menurunkan kecemasan santri baru dan terdapat perbedaan penurunan kecemasan ditinjau dari tipe kepribadian introvert dan ekstrovert. Metode penelitian ini kuasi eksperimen jenis non randomized control group pretest posttest design. Jumlah subjek 36 siswa terbagi dalam kelompok eksperimen yang diberi perlakuan SEFT dan kelompok kontrol. Pengambilan sampel menggunakan purposive sampling. Alat ukur penelitian menggunakan skala kecemasan dan skala kepribadian. Analisis data menggunakan Wilcoxon dan Mann Whitney. Hasil analisis Wilcoxon menunjukkan nilai $\mathrm{z}=-3.482$ dan $\mathrm{p}=0.000(\mathrm{p}<0.05)$ artinya terdapat pengaruh SEFT untuk menurunkan kecemasan santri baru, uji Mann Whitney menunjukkan nilai 17.500 dan $\mathrm{p}=0.042(\mathrm{p}<0.05)$ artinya terdapat perbedaan penurunan kecemasan ditinjau dari tipe kepribadian introvert dan ekstrovert. Tingkat rata-rata tipe kepribadian ekstrovert lebih rendah (6.94) dibandingkan tipe kepribadian introvert (12.06).
\end{abstract}

Kata Kunci : SEFT, Kecemasan Santri Baru, Tipe Kepribadian

\begin{abstract}
Study aims to test the effectiveness of SEFT to lower anxiety new students in terms of introverted and extroverted personality. The hypothesis of this research is the SEFT to lower anxiety new students and there is a decrease anxiety in terms of introverted and extroverted personality. Methodology of this quasi nonrandomized control group experiment pretest posttest design. Subject 36 students divided into groups experiment who were given treatment SEFT and control groups. Sample used purposive sampling. Measuring instrument the research uses scale anxiety and scale of personality. Analysis data using wilcoxon and mann whitney. Analysis score wilcoxon $z=-3.482$ and $p=0.000$ $(p<0.05)$ it means there were influence seft to lower new students anxiety, score mann whitney 17.500 and $p=0.042(p<0.05)$ means there is a difference in the anxiety in terms of personality and type introverted extroverted. The rinks mean type personality extroverted lower (6.94) than type personality introverted (12.06).
\end{abstract}

Keywords: SEFT, Anxiety New Students, Personality Type

1 email : rizkimaula7@gmail.com

Fakultas Psikologi Universitas 17 Agustus 1945 Surabaya

Jl. Semolowaru No.45, Menur, Surabaya

Efektivitas Spiritual Emotional Freedom Technique (Seft) Untuk Menurunkan Kecemasan Santri Baru Ditinjau Dari Tipe Kepribadian Rizki Maulana Hidayatullah, Igaa Noviekayati, Sahat Saragih 


\section{Pendahuluan}

Manusia merupakan mahluk yang tidak bisa lepas dari permasalahan. Tidak jarang permasalahan tersebut menimbulkan gangguan psikologi, yang salah satunya adalah kecemasan. Menurut Nevid (2005) Kecemasan (anxiety) adalah suatu keadaan aprehensi atau keadaan khawatir yang mengeluhkan bahwa sesuatu yang buruk akan segera terjadi. Kecemasan dapat berakibat buruk pada seseorang jika tidak ditemukan penyelesaian atau coping yang efektif. Kecemasan yang berlebihan tidak hanya dialami oleh manusia pada usia tertentu saja, namun fenomena baru-baru ini menunjukkan kecemasan mudah dialami oleh para pelajar remaja. Ketidak efektifan dalam penerapan coping menyebabkan timbulnya perilaku negatif pada remaja. Kasus-kasus yang terkait kecemasan yang berlebihan pada pelajar remaja kini sudah banyak terjadi. Begitupun kecemasan yang terjadi pada para santri yang masih berada pada usia remaja di pondok pesantren.

Santri merupakan seorang pelajar yang melakukan aktivitas pendidikan dalam 24 jam di dalam suatu pesantren. Selain padatnya aktivitas yang dilakukan santri, tuntutan yang harus dilakukan juga sangat banyak, seperti hafalan Al Qur'an, sya'ir-sya'ir, hadis, do'a dan masih banyak lagi (Faiqoh, 2003). Pondok pesantren mamiliki kegiatan pembelajaran yang sama dengan sekolah formal pada umumnya namun di pondok pesantren lebih fokus dengan kegiatan seperti sekolah diniyah, menghafal dan memahami Al-Quran, hadist, bahasa arab, serta pelatihan untuk menghadapi situasi saat dimasyarakat nantinya seperti pidato di depan umum, memimpin pengajian, sehingga tidak jarang kegiatan tersebut membuat santri mengalami kecemasan (Aminullah, 2013).

Padatnya kegiatan yang dilakukan santri tentunya membuat mereka merasa kelelahan khususnya yang bagi santri baru. Menurut Beck \& Emery (dalam Mu'arifah, 2005) bahwa ketidakseimbangan neurogemis tertentu atau kelelahan, pada taraf tertentu menjadi penyebab munculnya perasaan bahaya dan timbulnya gangguan kecemasan. Kelelehan yang santri alami baik akibat aktivitas maupun tuntutan yang harus santri kuasai adalah salah satu alasan yang dapat memunculkan kecemasan dan hal itu tentunya dapat menjadi kendala dalam proses belajar mereka di pesantren.

Seperti dari hasil penelitian yang dilakukan oleh Siregar (2013) kepada 78 santri di pondok pesantren Nurul Huda, Singosari, Malang. Berdasarkan hasil analisis didapatkan data sebesar $19,2 \%$ atau 15 santri mengalami tingkat kecemasan rendah. Sementara yang mengalami tingkat kecemasan sedang, sebesar $66,7 \%$ atau 52 santri. Sisanya sebesar $14,1 \%$ atau 11 santri mengalami kecemasan dengan tingkat tinggi. Dari penelitian tersebut menunjukkan rata-rata santri memiliki tingkat kecemasan sedang, serta $14,1 \%$ santri mengalami tingkat kecemasan yang tinggi. 
Penelitian lain yang dilakukan oleh Aminullah (2013) kepada 84 siswa kelas 1 SMP dari sekolah umum dan pesantren yang ada di Singosari, Malang. Dari hasil penelitian tersebut menunjukkan tingkat kecemasan santri kelas 1 SMP lebih tinggi dibandingkan siswa dari sekolah umum dengan tingkat signifikan 0,000 $(p<0,05)$. Dari beberapa penelitian menunjukkan tingkat kecemasan pada kategori sedang hingga tinggi terdapat pada santri yang berada di pesantren. Kecemasan yang menjadi kendala dalam proses pendidikan banyak ditemukan di lingkungan pesantren, karenanya perlu adanya penanganan khusus untuk mengatasi kecemasan yang dialami oleh santri.

Kecemasan yang ada dalam proses pendidikan di pesantren sebenarnya tidak semua santri mengalaminya. Kecemasan juga bisa terjadi pada tingkat usia atau pendidikan tertentu saja seperti halnya penelitian yang dilakukan oleh Harpell dan Andrews (2012) kepada 263 siswa SMP dan SMA yang berusia berkisar 1219 tahun dari kelas 7-12 bahwa dari hasil penelitiannya memberikan data bawasanya kecemasan siswa SMP sebesar 68,3\% sedangkan tingkat kecemasan siswa SMA (31,7\%), hal tersebut membuktikan bawasanya siswa SMP lebih banyak yang mengalami kecemasan dibandingka siswa SMA. Penelitian lain yang dilakukan oleh Siregar (2013) kepada 78 santri di pondok pesantren Nurul Huda, Singosari, Malang. Usia Santri yang paling banyak mengalami kecemasan adalah usia 13 tahun (26,9\%) dan usia yang paling sedikit adalah usia 17 tahun (7,7\%). Dari data tersebut diketahui bahwa usia paling rawan mengalami kecemasan adalah usia 13 tahun atau usia sekolah SMP dan usia yang paling kecil mengalami kecemasan adalah usia 17 atau usia sekolah SMA.

Dari penelitian di atas menunjukkan diantara usia 12, 13-19 tahun, yang paling rentang mengalami kecemasan adalah usia 12 dan 13 tahun. Hal tersebut dikarenakan keberadaan siswa di dalam proses pembelajaran yang ada di lingkungan baru Aminullah (2013). Lingkungan baru yang dijalani oleh santri baru dalam proses pembelajaran serta lingkungan hidup memberikan kemungkinan timbulnya kecemasan selain itu munculnya kecemasan pada anakanak dan remaja awal terjadi karena ketakukannya akan perpisahan dengan orang yang penting baginya seperti kehilangan anggota keluarga.

Menurut Jefrey, Spencer \& Beverly (2003) kecemasan pada anak-anak dan remaja awal terjadi karena ketakutan kehilangan yang berlebihan akan orang tua atau pengasuh lainnya dan didukung oleh pengalaman tarumatis yang terjadi di masa kanak-kanak, serta hal tersebut bisa terjadi hingga masa dewasa. Berdasarkan uraian tersebut, terlihat bahwa santri baru tidak jarang berada dikondisi yang mengarah pada kecemasan, baik kecemasan yang muncul dari proses pembelajaran maupun di lingkungan di pesantren. Hal tersebut 
memungkinkan kecemasan santri baru berdampak negatif dalam menjalankan aktivitas.

Kecemasan adalah pengalaman umum manusia dan merupakan emosi dasar manusia yang dapat didefinisikan sebagai kegelisahan, ketidaknyamanan, ketidakpastian, atau ketakutan dari suatu bahaya (Varcarolis \& Halter, 2010). Berdasarkan data statistik badan kesehatan dunia (WHO), menyatakan bahwa ada peningkatan kecemasan sebesar 2,5\% per tahun. Menurut Bureau (dalam Subandi 2013), bahwa: "Angka kejadian gangguan kecemasan di Indonesia sekitar 39 juta jiwa dari 238 juta jiwa penduduk". Prevalensi gangguan kecemasan diperkirakan antara 9\%-12\% dari populasi umum di Indonesia. Prevalensi nasional gangguan kecemasan menurut Riset Kesehatan Dasar (Riskesdas) (2013) menunjukkan bahwa remaja di Indonesia sebesar 6\% untuk usia 15 tahun ke atas atau sekitar 14 juta penduduk mengalami gangguan mental emosional yang ditunjukkan dengan gejala-gejala kecemasan dan depresi (Riskesdas, 2013).

Data yang diperoleh menegaskan bahwa permasalahan kecemasan di Indonesia sangat perlu untuk diperhatikan. sedangkan faktor yang menjadi pencetus munculnya kecemasan yang dialami seseorang, dapat berasal dari diri sendiri (internal) ataupun berasal dari luar dirinya sendiri (eksternal). Faktor yang berasal dari diri sendiri (internal) bisa berasal dari kepribadian orang tersebut. (dalam Sobur, 2013). Secara umum kepribadian menunjuk kepada sifat umum seseorang pikiran kegiatan dan perasaan yang berpengaruh secara sistemik terhadap keseluruhan tingkah laku, termasuk kecemasan yang dialami seseorang. kepribadian juga mengandung kecenderungan-kecenderungan menentukan (determinasi) yang memainkan peranan aktif dalam tingkah laku individu (Juntika., dkk 2010).

Jung (dalam Hall dan Lindzey, 1970) membedakan perilaku atau attitude menjadi dua kelompok perilaku mayor yakni attitude extraversion dan attitude intraversion dimana penggolongannya ini disebut sebagai orientasi dari kepribadian. Berdasarkan dua jenis perilaku tersebut, secara umum diartikan bahwa extroverted merupakan perilaku yang berorientasi terhadap dunia eksternal dan berorientasi pada dunia objektif, sedangkan attitude introvert merupakan perilaku individu yang berorientasi pada dunia internal atau inner serta dunia subjektif. Jung juga menambahkan bahwa kedua sikap perilaku berlawanan tersebut memiliki eksistensi masing-masing dalam individu namun terdapat salah satu yang dominan.

Eysenck (dalam Allen, 2003) mengemukakan bahwa seseorang yang memiliki tipe kecenderungan ekstrovert akan memiliki karakteristik sebagai berikut: mereka tergolong orang yang ramah, suka bergaul, menyukai pesta, memiliki banyak teman, selalu membutuhkan orang lain untuk diajak berbicara, dan menyukai segala bentuk kerja sama. Individu dengan tipe kepribadian 
ekstrovert tidak jarang selalu mengambil kesempatan yang datang pada mereka, tidak jarang menonjolkan diri, dan sering kali bertindak tanpa berfikir terlebih dahulu, secara umum termasuk individu yang meledak-ledak.

Tipe kepribadian ekstrovert memiliki tingkat kebiasaan cortical arousal yang rendah, mereka membutuhkan tingkat stimulasi sensorik tinggi untuk mempertahankan tingkat optimal stimulasi. Individu bertipe kepribadian ekstrovert lebih sering berpartisipasi dalam kegiatan menarik dan merangsang. Dari kedua jenis tipe kepribadian tersebut memiliki pengaruh terhadap kecemasan yang dialami oleh santri baru khususnya dalam proses beradaptasi dengan lingkungan pesantren.

Permasalahan kecemasan yang terjadi pada santri baru sangat perlu untuk diatasi, tentunya dengan penanganan kecemasan yang efektif seperti menggunakan SEFT (Spiritual Emotional Freedom Technique). SEFT bisa mengatasi berbagai permasalahan emosi pada manusia diantaranya: phobia (ketakutan berlebihan), trauma, depresi, gugup pada suatu hal, tidak percaya diri, latah, kesulitan konsentrasi belajar, mudah marah, kecemasan, dan stres (Bakara, Ibrahim, Sriati, 2013).

SEFT memandang jika aliran energi tubuh terganggu karena dipicu kenangan masa lalu atau trauma yang tersimpan dalam alam bawah sadar, maka emosi seseorang akan menjadi kacau. Mulai dari yang ringan, seperti bad mood, malas, tidak termotivasi melakukan sesuatu, hingga yang berat, seperti PSTD, depresi, phobia, kecemasan berlebihan dan stres emosional berkepanjangan. Sebenarnya semua ini penyebabnya sederhana, yakni terganggunya system energi tubuh. Karena itu solusinya juga sederhana, menetralisir kembali gangguan energi itu dengan SEFT. Aliran energi yang tersumbat di beberapa titik kunci tubuh harus dibebaskan, hingga mengalir lagi dengan lancar. Cara membebaskannya adalah dengan mengetuk ringan menggunakan dua ujung jari (tapping) di bagian tubuh tertentu. Berikut ini adalah uraian tentang bagaimana melakukan SEFT untuk membebaskan aliaran energi di tubuh, yang dengannya akan membebaskan emosi dari berbagai kondisi negatif (Zainuddin, 2009).

Berdasarkan hasil survei yang dilakukan pada pesantren Amanatul Ummah Pacet Mojokerto ditemukan kasus santri baru yang keluar dari pesantren akibat kecemasan yang berlebihan terhadap kehidupan di pesantren serta ketidaksiapan santri jauh dari orang tua atau keluarganya. Oleh karena itu peneliti tertarik untuk melakukan penelitian di pesantren Amanatul Ummah Pacet Mojokerto dengan judul penelitian "Efektivitas SEFT Untuk Menurunkan Kecemasan Santri Baru Ditinjau Dari Tipe Kepribadian”.

Efektivitas Spiritual Emotional Freedom Technique (Seft) Untuk Menurunkan Kecemasan Santri Baru Ditinjau Dari Tipe Kepribadian 


\section{Metode Penelitian}

Metodelogi penelitian yang digunakan adalah metode penelitian eksperimen. Desain eksperimen yang digunakan peneliti yaitu quasi eksperimen dengan jenis non randomized control group pretest posttest design. Desain ini melibatkan dua kelompok tanpa melakukan randomisasi, satu diberi perlakuan eksperimenal (kelompok eksperimen) dan yang lain tidak diberi perlakuan apaapa (kelompok kontrol). Adapun teknik pengumpulan data yang digunakan adalah kuisioner dengan pengukuran skala likert. Teknik analisis data penelitian menggunakan uji wilcoxon dan mann whitney dengan bantuan program aplikasi komputer berbasis SPSS 20.0 for windows untuk membuktikan keabsahan data.

\section{Hasil dan Pembahasan}

Hasil dari uji validitas ditemukan skor item skala kecemasan berkisar 0.3170.656 dengan jumlah keseluruhan 42 item, terdapat 7 item dinyatakan gugur dan 35 item dinyatakan valid. Sedangkan hasil uji validitas pada skala tipe kepribadian dari skor nilai item terendah sebesar -0.024 sampai skor item tertinggi sebesar 0.601. Hasil pengujian validitas skala tipe kepribadian berkisar dari 0.318-0.599 dengan jumlah keseluruhan 54 item diperoleh 12 item dinyatakan gugur, sedangkan item yang dinyatakan valid sebanyak 42 item.

Hasil pengujian reliabilitas skala perilaku seks bebas dan tipe kepribadian diperoleh hasil yang reliabel, yaitu skala kecemasan dengan nilai cronbach's alpha ( $\alpha$ ) 0.918 dan dari skala tipe kepribadian dengan nilai cronbach's alpha $(\alpha)$ 0.922. Dari hasil pengujian tersebut maka alat ukur skala kecemasan dan skala tipe kepribadian dianggap reliabel atau andal.

Adapun kriteria yang dijadikan sampel dalam penelitian ini adalah: (1) Siswasiswi santri baru kelas 7 di SMP BP Unggulan Pondok Pesantren Amanatul Ummah Pacet yang memiliki tingkat kecemasan kategori tinggi dan sangat tinggi dengan tipe kepribadian introvert dan ekstrovert. (2) Bersedia menjadi dan mengikuti keseluruhan dari proses penelitian. terdapat 36 subjek sample penelitian, terdiri dari 18 subjek tipe kepribadian introvert, dan 18 subjek tipe kepribadian ekstrovert. Selanjutnya peneliti membagi setiap tipe kepribadian menjadi dua untuk mengelompokkan kedalam kelompok eksperimen dan kelompok kontrol yaitu 9 subjek introvert dan 9 subjek ekstrovert dimasukkan kedalam kelompok eksperimen serta 9 subjek introvert dan 9 subjek ekstrovert dimasukkan kedalam kelompok kontrol.

Analisis penelitian yang pertama dengan menggunakan Wilcoxon yaitu sebuah tes hipotesis non parametik yang digunakan untuk menguji perbedaan data pre test dengan post test baik pada kelompok eksperimen maupun kelompok kontrol. Analisis penelitian yang kedua menggunakan Mann Whitney Test untuk 
menguji antara nilai kecemasan subjek dengan tipe kepribadian introvert dan subjek dengan tipe kepribadian ekstrovert.

Data yang telah diperoleh dari nilai kecemasan pretest dan postest kelompok eksperimen maupun data dari nilai kecemasan pretest dan postest kelompok kontrol di lakukan analisa uji beda non parametric yaitu uji wilcoxon dan Mann Whitney Test.

Tabel 1. Hasil Uji Wilcoxon Kelompok Eksperimen Dan Kelompok Kontrol

$\begin{array}{lc}\text { Pre Test Kelompok } & \text { Pre Test Kelompok Kontrol- Post } \\ \text { Eksperimen - Post Test } & \text { Test Kelompok Kontrol } \\ \text { Kelompok Eksperimen } & \end{array}$

\begin{tabular}{lrr}
\hline $\mathbf{Z}$ & $-3.482^{\mathrm{b}}$ & $.000^{\mathrm{c}}$ \\
\hline Sig & .000 & 1.000 \\
\hline
\end{tabular}

Berdasarkan tabel di atas diketahui hasil uji z pada data pre test dan post test kelompok eksperimen menunjukkan nilai $\mathrm{z}=-3.482$ sedangkan nilai $\mathrm{p} 0.000$ $(\mathrm{p}<0.05)$ hal tersebut mengartikan terdapat pengaruh yang signifikan antara data pre test dan post test pada kelompok eksperimen selain itu jika dilihat dari data nilai mean peringkat penurunan tingkat kecemasan sebesar 10.00 hal tersebut mengartikan terdapat pengaruh yang positif pemberian SEFT dalam menurunkan tingkat kecemasan. Berdasarkan tabel di atas diketahui hasil uji z pada data pre test dan post test kelompok kontrol menunjukkan nilai $\mathrm{z}=0.000$ sedangkan $\mathrm{p}=0.790 \quad(\mathrm{p}>0.05) \quad$ hal tersebut mengartikan tidak terdapat pengaruh yang signifikan antara data pre test dan post test pada kelompok kontrol.

Tabel 2. Hasil Uji Wilcoxon KE Dan KK Ditinjau Dari Tipe Kepribadian

\begin{tabular}{|c|c|c|c|c|}
\hline & $\begin{array}{c}\text { Pre Test KE } \\
\text { Introvert - Post } \\
\text { Test KE } \\
\text { Introvert }\end{array}$ & $\begin{array}{c}\text { Pre Test KE } \\
\text { Ekstrovert- Post } \\
\text { Test KE } \\
\text { Ekstrovert }\end{array}$ & $\begin{array}{c}\text { Pre Test } \\
\text { KKIntrovert - } \\
\text { Post Test KK } \\
\text { Introvert }\end{array}$ & $\begin{array}{c}\text { Pre Test KK } \\
\text { Ekstrovert - Post } \\
\text { Test KK Ekstrovert }\end{array}$ \\
\hline$\overline{\mathbf{Z}}$ & $-2.312^{b}$ & $-2.521^{b}$ & $-.924^{c}$ & $-1.377^{b}$ \\
\hline$\overline{\text { Sig }}$ & .021 & .012 & .356 & .168 \\
\hline
\end{tabular}

Berdasarkan tabel di atas diketahui hasil uji z pada data pre test dan post test kelompok eksperimen dengan tipe kepribadian introvert menunjukkan nilai $\mathrm{z}=$ -2.312 dan nilai $\mathrm{p}=0.021 \quad(\mathrm{p}<0.05)$ hal tersebut menunjukkan terdapat pengaruh yang signifikan antara data pre test dan post test pada kelompok eksperimen dengan tipe kepribadian introvert. Sedangkan hasil uji t pada data pre test dan post test kelompok eksperimen dengan tipe kepribadian ekstrovert menunjukkan nilai $\mathrm{z}=-2.521$ dan nilai $\mathrm{p}=0.012(\mathrm{p}<0.05)$ hal tersebut menunjukkan terdapat pengaruh

Efektivitas Spiritual Emotional Freedom Technique (Seft) Untuk Menurunkan Kecemasan Santri Baru Ditinjau Dari Tipe Kepribadian Rizki Maulana Hidayatullah, Igaa Noviekayati, Sahat Saragih 
yang signifikan antara data pre test dan post test pada kelompok eksperimen dengan tipe kepribadian ekstrovert.

Hasil uji z pada data pre test dan post test kelompok kontrol dengan tipe kepribadian introvert menunjukkan nilai $\mathrm{p}=0.356 \quad(\mathrm{p}>0.05)$ hal tersebut mengartikan tidak terdapat pengaruh yang signifikan antara data pre test dan post test pada kelompok kontrol dengan tipe kepribadian introvert. Sedangkan hasil uji $\mathrm{z}$ pada data pre test dan post test kelompok kontrol dengan tipe kepribadian ekstrovert menunjukkan nilai $\mathrm{p}=1.377$ ( $\mathrm{p}>0.05$ ) hal tersebut mengartikan tidak terdapat pengaruh yang signifikan antara data pre test dan post test pada kelompok kontrol dengan tipe kepribadian ekstrovert.

Berdasarkan analisa data uji z di atas bahwasanya data pre test dan post test kelompok eksperimen dengan tipe kepribadian introvert dan tipe kepribadian ekstrovert dengan memberikan perlakuan berupa SEFT memiliki pengaruh terhadap turunnya tingkat kecemasan dan data pre test dan post test kelompok kontrol dengan tipe kepribadian introvert dan tipe kepribadian ekstrovert tidak memberikan pengaruh terhadap tingkat kecemasan. Berdasarkan analisa di atas maka perlu dilakukan uji Mann Whithney yang digunakan untuk mengetahui lebih efektif mana SEFT diberikan kepada subjek dengan tipe kepribadian introvert ataukah subjek dengan tipe kepribadian ekstrovert dalam hal menurunkan tingkat kecemasan.

Tabel 3. Hasil Tingkatan Rata-Rata Posttest Introvert dan Posttest Ekstrovert KE

\begin{tabular}{llccc}
\hline Kelompok & N & Mean Rank Sum of Ranks \\
\hline \multirow{2}{*}{ Nilai } & $\begin{array}{l}\text { Pos Test Tipe Kepribadian Introvert } \\
\text { Kelompok Eksperimen }\end{array}$ & 9 & 12.06 & 108.50 \\
\cline { 2 - 5 } & $\begin{array}{l}\text { Pos Test Tipe Kepribadian Ekstrovert } \\
\text { Kelompok Eksperimen }\end{array}$ & 9 & 6.94 & 62.50 \\
\cline { 2 - 4 } & Total & \multicolumn{2}{c}{18} & \\
\hline
\end{tabular}

Tabel 4. Hasil Uji Mann Whitney Post Test Introvert dan Post Test Ekstrovert KE

\begin{tabular}{lc}
\hline & Nilai \\
Mann-Whitney U & 17.500 \\
Wilcoxon W & 62.500 \\
Z & -2.032 \\
Asymp. Sig. (2-tailed) & .042 \\
Exact Sig. [2*(1-tailed Sig.)] & $.040^{\text {b }}$ \\
\hline
\end{tabular}

Berdasarkan tabel di atas diketahui hasil uji Mann-Whitney pada data post test kelompok eksperimen yang memiliki tipe kepribadian introvert dan post test kelompok eksperimen yang memiliki tipe kepribadian ekstrovert menunjukkan nilai 17.500 dan nilai $\mathrm{p}=0.042(\mathrm{p}<0.05)$ hal tersebut mengartikan terdapat perbedaan yang signifikan antara data post test kelompok eksperimen yang 
memiliki tipe kepribadian introvert dan post test kelompok eksperimen yang memiliki tipe kepribadian ekstrovert. Jika dilihat dari tingkat mean post test kelompok eksperimen yang memiliki tipe kepribadian introvert sebesar 12.06 dan post test kelompok eksperimen yang memiliki tipe kepribadian ekstrovert 6.94 hal tersebut menunjukkan jika tipe kepribadian ekstrovert lebih efektif menerima SEFT karena memiliki tingkat mean lebih rendah dibandingkan dengan tipe kepribadian introvert.

Hasil penelitian membuktikan bahwa hipotesis pertama diterima karena secara simultan ditemukan ada pengaruh yang sangat signifikan dalam pemberian SEFT untuk menurunkan tingkat kecemasan. Sedangkan pada kelompok kontrol yang tidak diberikan perlakuan menunjukkan tidak ada perubahan tingkat kecemasan secara signifikan. Penelitian ini menunjukkan bahwa variabel bebas/ independent (SEFT) mempengaruhi variabel terikat/ dependent (tingkat kecemassan).

Hasil penelitian ini secara umum telah menjawab permasalahan penelitian yang telah dirumuskan sebelumnya bahwa terdapat pengaruh SEFT untuk menurunkan tingkat kecemasan pada siswa baru kelas 7 SMP BP Unggulan di pondok pesantren Amanatul Ummah Pacet. Semakin sering pemberian SEFT diberikan, maka semakin menurun pula tingkat kecemasan siswa.

Pemberian SEFT kepada siswa baru kelas 7 SMP BP Unggulan di Pondok Pesantren Amanatul Ummah Pacet terbukti sangat efektif untuk menurunkan tingkat kecemasan. SEFT bisa mengatasi berbagai permasalahan emosi pada manusia diantaranya: phobia (ketakutan berlebihan), trauma, depresi, gugup pada suatu hal, tidak percaya diri, latah, kesulitan konsentrasi belajar, mudah marah, kecemasan, dan stres (Bakara, Ibrahim, Sriati, 2013). Church \& Brooks (2010) berdasarkan hasil penelitiannya juga berpendapat bahwa spiritual emotional freedom technique (SEFT) dapat menurunkan kecemasan, depresi, dan nyeri. Hal tersebut selaras dengan hasil penelitian setelah diberikan SEFT kepada siswa baru kelas 7 SMP BP Unggulan di Pondok Pesantren Amanatul Ummah Pacet tingkat kecemasan siswa terlihat mengalami penurunan yang karena pada siswa yang tidak diberikan perlakuan tidak terdapat perubahan tingkat kecemasannya.

SEFT memandang jika aliran energi tubuh terganggu karena dipicu kenangan masa lalu atau trauma yang tersimpan dalam alam bawah sadar, maka emosi seseorang akan menjadi kacau. Mulai dari yang ringan, seperti bad mood, malas, tidak termotivasi melakukan sesuatu, hingga yang berat, seperti PSTD, depresi, phobia, kecemasan berlebihan dan stres emosional berkepanjangan. Sebenarnya semua ini penyebabnya sederhana, yakni terganggunya sistem energi tubuh. Karena itu solusinya juga sederhana, menetralisir kembali gangguan energi itu dengan SEFT. Aliran energi yang tersumbat di beberapa titik kunci tubuh harus

Efektivitas Spiritual Emotional Freedom Technique (Seft) Untuk Menurunkan Kecemasan Santri Baru Ditinjau Dari Tipe Kepribadian 
dibebaskan, hingga mengalir lagi dengan lancar. Cara membebaskannya adalah dengan mengetuk ringan menggunakan dua ujung jari (tapping) di bagian tubuh tertentu. Berikut ini adalah uraian tentang bagaimana melakukan SEFT untuk membebaskan aliaran energi di tubuh, yang dengannya akan membebaskan emosi dari berbagai kondisi negatif (Zainuddin, 2009).

Hipotesis ke dua dalam penelitian ini diterima karena secara simultan ditemukan perbedaan yang sangat signifikan dalam penurunan tingkat kecemasan ditinjau dari tipe kepribadian setelah dilakukan SEFT. Penelitian ini menunjukkan bahwa variabel bebas/ independent (tipe kepribadian) mempengaruhi variabel terikat/ dependent (kecemasan). Hasil penelitian menunjukkan bahwa pemberian SEFT lebih efektif untuk menurunkan kecemasan pada siswa baru kelas 7 SMP BP Unggulan di Pondok Pesantren Amanatul Ummah Pacet meskipun pada subjek dengan tipe kepribadian introvert efektif namun subjek dengan tipe kepribadian ekstrovert jauh lebih efektif menurunkan tingkat kecemasan. Hal ini menunjukkan jika individu dengan tipe kepribadian ekstrovert menggambarkan keunikan individu dalam bertingkah laku terhadap stimulus sebagai suatu perwujudan karakter, tempramen, fisik dan intelektual individu dalam menyesuaikan diri dengan lingkungannya. Dua jenis tipe kepribadian tersebut memiliki pengaruh terhadap kecemasan yang dialami oleh santri baru khususnya dalam proses beradaptasi dengan lingkungan pesantren.

Faktor yang mempengaruhi kecemasan siswa baru salah satunya adalah tipe kepribadian. Tipe kepribadian turut menentukan respon seseorang, termasuk munculnya kecemasan. Kepribadian adalah keseluruhan cara seorang individu bereaksi dan berinteraksi dengan individu lain. Kepribadian merupakan suatu organisasi yang dinamis dari sistem psiko-fisik indvidu yang menentukan tingkah laku dan pemikiran individu secara khas (Suryabrata, 2003). Menurut Jung kepribadian di bedakan menjadi dua, yakni introvert dan ekstrovert. Dikatakan introvert jika sikap kesadaran seseorang mengarah kedalam dirinya sendiri. Sedangkan ekstrovert artinya sikap kesadaran yang mengarah ke luar dirinya, yaitu kepada alam sekitar dan manusia lain.

Berdasarkan struktur hirarki Eysenck tentang trait kepribadian utamanya, ekstrovert memiliki sembilan trait yakni mudah bergaul (sociable), lincah (lively), aktif (active), asertif (assertive), mencari sensasi (sensation seeking), periang (carefree), dominan (dominance), bersemangat (surgent), berani (venturesome) (Feist, 2002). Seseorang dengan tipe kepribadian ekstrovert memiliki sifat mudah bergaul sehingga mudah beradaptasi ketika diberikan SEFT oleh pemateri selain itu sikap orang yang memiliki tipe kepribadian ekstrovert yang selalu aktif, bersemangat dan berani untuk mencoba hal baru serta motivasi yang tinggi dalam keinginannya dihargai oleh orang lain membuat orang dengan tipe kepribadian 
ekstrovert bersemangat untuk berubah menjadi lebih baik khususnya dalam menurunkan tingkat kecemasannya.

Eysenck (dalam Alwisol, 2009) menjelaskan bahwa ekstroverti merupakan jenis sifat bawaan (trait) yang berorientasi pada sikap-sikap objektif dan tidak pribadi. Beberapa sikap yang menunjukkan perilaku ekstraversi adalah sikap sociable atau pandai dan mudah dalam bergaul, lincah, cenderung aktif, asertif, memiliki kecenderungan mencari sensasi, periang, dominan, bersemangat dan berani dalam hal ini berhubungan dengan kecenderungan mengambil resiko. Seseorang dengan perilaku yang cenderung aktif, lincah, dan bersemangat inilah yang membuat seseorang yang memiliki tipe kepribadian ekstrovert lebih mudah untuk menerima SEFT dengan lebih baik.

Sedangkan tipe kepribadian introvert tidak hanya memiliki keterkaitan dengan tipologi sikap dari Jung, melainkan juga memiliki keterkaitan dengan konsep introvertion dalam teori yang digagas oleh Eysenck. Introvertion merupakan sebuah disposisi atau watak dari dimensi karakteristik kepribadian yang menunjukkan kebalikan dari trait ekstrovert, yaitu sulit bergaul, statis, pasif, ragu, taat aturan, sedih, minus, lemah, dan penakut (Feist, 2002). Dengan kepribadian yang cenderung lemah, penakut untuk mencoba hal baru, sulit bergaul khususnya dengan pemateri SEFT orang yang baru dikenal, dan ragu-ragu membuat seseorang dengan tipe kepribadian introvert sulit untuk menerapkan SEFT dengan maksimal.

Individu dengan tipe kepribadian ekstrovert lebih efektiv dalam menerima SEFT karena lebih cepat tanggap dalam menerima informasi. Lebih cepat tanggap terhadap stimulus yang diterima serta menyukai perubahan, tidak terlalu memusingkan suatu masalah dan memiliki sifat optimis. Pemberian SEFT yang dilakukan oleh seorang yang terlatih menjadi salah satu faktor efektifnya SEFT untuk menurunkan kecemasan siswa baru kelas 7 SMP BP Unggulan di Pondok Pesantren Amanatul Ummah Pacet sehingga pemberian SEFT mampu mempengaruhi tingkat kecemasannya.

\section{Kesimpulan}

Penelitian ini bertujuan menguji pengaruh terapi SEFT untuk menurunkan kecemasan santri baru di Pesantren Amanatul Ummah dan menguji perbedaan signifikan penurunan kecemasan santri baru ditinjau dari tipe kepribadian setelah dilakukan terapi SEFT. Penelitian ini dilakukan terhadap 36 siswa baru kelas 7 SMP BP Unggulan di Pondok Pesantren Amanatul Ummah Pacet yang memiliki tingkat kecemasan sangat tinggi dan tinggi dengan meninjau dari tipe kepribadian introvert dan ekstrovert. Desain penelitian ini menggunakan quasi experiment. 
Teknik pengambilan sampel penelitian yang digunakan adalah purposive random sampling. Analisis data menggunakan metode uji-t.

Berdasarkan hasil analisis data dengan uji-t pada kelompok eksperimen, dan kelompok kontrol diketahui bahwa terjadi penurunan tingkat kecemasan yang signifikan setelah diberikan SEFT. Dapat disimpulkan bahwa SEFT berpengaruh untuk menurunkan tingkat kecemasan pada siswa baru kelas 7 SMP BP Unggulan di Pondok Pesantren Amanatul Ummah Pacet baik yang bertipe kepribadian introvert maupun ekstrovert. Berikut kesimpulannya:

1. Analisa data uji Wilcoxon pada kelompok eksperimen menunjukkan pengaruh yang signifikan antara sebelum dan sesudah diberikan SEFT sedangkan pada kelompok kontrol yang tidak diberikan perlakuan apapun tidak terdapat perubahan tingkat kecemasannya secara signifikan. Selain itu jika dilihat dari rata-rata terdapat penurunan tingkat kecemasan dari sebelum dan sesudah diberikan SEFT.

2. Analisa data uji Mann Whitney pada kelompok eksperimen menunjukkan SEFT lebih efektif pada subjek dengan tipe kepribadian ektrovet dibandingkan dengan subjek dengan tipe kepribadian introvert hal tersebut dikarnakan subjek dengan tipe kepribadian ekstrovert lebih terbuka dalam menerima informasi dari luar seperti pemberian SEFT dibandingkan dengan subjek yang memiliki tipe kepribadian introvert yang cenderung lebih tertutup.

\section{Daftar Pustaka}

Allen, D. G., Shore, L. M. \& Griffeth, R. W. (2003). The role of perceived organizational support and supportive human resource practices in turnover process. Journal of Management, 99-118

Aminullah, A. (2013). Kecemasan antara siswa SMP dan santri pondok pesantren. Jurnal Online Psikologi, 01 (02)

Alwisol. (2009). Psikologi Kepribadian. Edisi Revisi. Malang: UMM Press

Bakara, D.M., Ibrahim, K. \& Sriati, A. (2013). Pengaruh Spiritual Emotional Freedom Technique (SEFT) Terhadap gejala Depresi, Kecemasan dan Stress pada Pasein Sindrom Koroner Akut (SKA) Non Percutaneous Coronary intervention (PCI). Jurnal Keperawatan Padjajaran. Vol. 1. No. 1. Universitas Padjajaran Bandung

Faiqoh, B. (2003). Agen Perubahan di Pesantren. Jakarta: Kucica

Feist, Jess, \& Gregory, J.F (2008). Theories Of Personality. Terj.yudi Santoso. 
Ed: 4. Yogyakarta: Pustaka pelajar

Feist, Jess, \& Gregory J.F. (2008). Theories Of Personality. Terj.yudi Santoso. Ed: 6. Yogyakarta: Pustaka pelajar

Hall S., Calvin, \& Gardner, L. (2005). Teori-Teori Psikodinamik (KLINIS), Ter. Penerbit. cet: 15 . Yogyakarta: Kanisius

Harpell, V. \& Andrews, W. (2012). Multi-Informant Test Anxiety Assessment of Adolescents. Psychology, 3 (7)

Jefrey, S., Spencer, A. \& Beverly, G. (2003). Abnormal psikologi in a changing world: Psikologi abnormal. (jilid 1). (Terj. Jeanete, dkk). Jakarta: Erlangga

Jefrey, S., Spencer, A. \& Beverly, G. (2003). Abnormal psikologi in a changing world: Psikologi abnormal. (jilid 2). (Terj. Jeanete, dkk). Jakarta: Erlangga

Juntika, N. \& Yusuf, S. (2010) Landasan Bimbingan dan Konseling. Bandung: PT. Remaja Rosdakarya

Mu'arifah, A. (2005). Hubungan Kecemasan Dan Agresivitas. Humanitas: Indonesian Psychological Journal, 2 (2) 102 - 111

Nevid, J., dkk., (2005). Psikologi Abnormal. Ed. 5. Jakarta: Erlangga

Riset Kesehatan Dasar (Riskesdas) (2013). Pedoman Pewawancara Petugas Pengumpul Data. Jakarta: Badan Litbangkes, Depkes RI

Siregar, N. (2013). Tingkat kecemasan pada santri pondok pesantren. Jurnal Online Psikologi, 01 (01)

Sobur, A. (2013). Psikologi Umum dalam Lintas Sejarah. Bandung: Pustaka Setia

Subandi, L.R. \& Suprianto T. (2013). Pengaruh Terapi Psikoreligius TerhadapPenurunan Tingkat Ansietas Pada Lansia di UPT Pelayanan Sosial LanjutUsia Sejahtera Pandaan Pasuruan

Suryabrata. (2003). Psikologi Kepribadian. Jakarta: PT. Raja Grafindo Persada

Varcarolis E. M. \& Halter M. J. (2010). Foundation of psychiatric mental health nursing a clinical approach. 6th edition. Saunders Elseviers. New York

Zainuddin, A.F. (2009). Spiritual Emotional Freedom Technique (SEFT) for Healing Succsess Happines Greatness. Jakarta: Afzan Publishing. 